Marcelle Auclair

\title{
Journée de convalescence
}

A Maria Perlaza

10.0 De ma chambre, où le dernier feu meurt sous la cendre, J'ai entendu tomber la pluie, rôder le vent, J'ai regardé ce long jour gris naître et descendre...

Je fus un front fébrile appuyé au cristal Où, d'un fin doigt d'argent, la pluie frappe et ruisselle, Et, près du brasere paisible, je fus celle Dont les yeux sont embués d'ennui doux ef banal.

Maitenant, il fait nuit. L'ombre, en la chambre basse, Lentement est montée, marée douce, flot noir. Et, dans l'obscurité, je ne puis plus que voir Pâlir, sur mes genoux brisés, mes deux mains lasses... 